\title{
LITHOLOGICAL AND PALEOGEOGRAPHIC CONDITIONS FOR THE FORMATION AND LOCATION OF SEDIMENTARY BASINS OF THE CASPIAN REGION
}

\author{
Senin B.V. ${ }^{1}$, Kerimov V.Yu. ${ }^{2}$, Mustaev R.N. ${ }^{2}$, Aliyeva S.A. ${ }^{3}$ \\ 1JSC "Yuzhmorgeologiya" \\ 353461, Russian Federation, Gelendzhik, Krymskaya str., 20 \\ ${ }^{2}$ Sergo Ordzhonikidze Russian State University for Geological Prospecting \\ 117997, Russian Federation, Moscow, Miklouho-Maklay str. 23 \\ ${ }^{3}$ Azerbaijan State Oil and Industry University \\ AZ1000, Baku, Azerbaijan, Azadlig prosp., 16/21
}

Keywords: Caspian region, reconstruction, lithological and formational aspects, paleogeographic conditions, sedimentary basins
Summary. The article discusses the lithological and paleogeographic conditions of the formation and location of sedimentary basins of the Caspian region. Its main feature of morphology and structure is the presence of superdeep depressions.

Non-palinspastic lithological-paleogeographic reconstructions performed using classical methods of thickness and facies analysis, showed that in the Middle-Late Triassic and Early Jurassic continental conditions prevailed in most of the Caspian region with the accumulation of terrigenous, less often carbonate, and in some places volcanogenic sedimentary strata. In the Middle Jurassic, large areas of stable subsidence and inundation appeared, and in the Late Jurassic and Early Cretaceous, predominantly marine conditions were established in the region with a predominance of carbonate sedimentation in some zones. In the Late Cretaceous, the entire region was a clay-carbonate shelf, in places over-deepened. At the end of the Paleogene - Early Miocene, in the southern part of the region, the processes of arch formation and orogenesis intensified, which were accompanied by the draining of the zones of orogenesis and some areas of the Northern and Eastern Caspian Sea, and the formation of over-deepened shelf troughs ahead of the front of the zone of active orogenesis with the predominance of terrigenous sedimentation in them. Substantial drainage of the territory of the Middle and North Caspian took place in the Pliocene, when in the relict, relatively deep sea depressions of the South and Middle Caspian region south of $42^{\circ} \mathrm{N}$ lat. formed powerful delta complexes of Pliocene rivers flowing from the East European platform and, in part, from the Turan plate.

The results of the reconstructions made it possible to restore the conditions and environments of sedimentation characteristic of the Caspian region in a long historical and geological retrospective and to obtain the necessary information for the subsequent numerical modeling of sedimentary basins and evolution of their hydrocarbon systems.

(C) 2021 Earth Science Division, Azerbaijan National Academy of Sciences. All rights reserved.

\section{Introduction}

The purpose of this work is to study the regional historical-geological, paleogeographic and lithological-formational aspects characterizing the formation conditions and distribution patterns of sedimentary basins of the Caspian region.

The main feature of the morphology and structure of the Caspian region is the presence of superdeep depressions. Characterization of the formation conditions and patterns of distribution of sedimentary basins in the
Caspian region is based on the results of lithological and paleogeographic reconstructions. The main sources were the results of field and laboratory studies, analysis of geological maps and materials of production and thematic reports for individual regions and areas of the studied region, as well as a number of publications (Глумов и др., 2014; Senin, 2012; Kerimov et al., 2017, 2018; Керимов и др., 2014, 2015, 2017).

In the study of regional historical-geological, paleogeographic and lithological-formational aspects 
characterizing the formation conditions and patterns of distribution of sedimentary basins of the Caspian region, elements of classical methods of non-palinspastic reconstructions of sedimentation conditions in the geological past were used (Белоусов, 1989; Леонов, 1993; Левин, Сенин, 2003; Холодов, Туровский, 1985).

\section{Research methodology}

The main methods used in the process of work include: paleogeographic reconstructions and construction of consolidated structural maps. During the process of research, in order to study the Caspian region and adjacent territories, classical methods of reconstructing the conditions of sedimentation in the geological past, such as analysis of thicknesses and facies, formation composition of sediments, interruptions and unconformities, as well as a large amount of published and stock data were used.

To construct reconstructions of basin evolution in the area under consideration, all currently available regional geological, geophysical, lithologicalpetrological, lithological-stratigraphic and other data on its structure were collected and systematized.

\section{Research results and discussion}

The geochronological interval encompassed by the reconstructions covers the period from the Middle Triassic to the Balakhanian time of the Pliocene. At the same time, the reconstructions occupy the Caspian waters and adjacent territories as far as they are provided with geological and geophysical data and corresponding structural constructions (Алиев, 1982). In this regard, the conditions of the basins in the Mesozoic are considered for the middle and northern parts of the subregion, which are provided with the indicated data in the required volumes and scales, and in the Cenozoic - for the entire region as a whole.

Middle-Late Triassic (Fig. 1). At the boundary of the Early and Middle Triassic, a relatively stable marine brackish-water regime is established in the central part of the Caspian, surrounded by a wide zone of periodically flooded territories, abounding in lagoons, runoff troughs and narrow straits.

In the Late Triassic, against the background of the general uplift of the region and regression of the basin, sea conditions persist only in separate, temporarily connected deep depressions, the general outline of which corresponds to the most bowed zone of the ancient Permian-Triassic basin. A relatively deep-sea basin at this time exists in the Greater Caucasus.

On the western and eastern outskirts of the Central Caspian basin (from the modern Kizlyar Bay to South Mangyshlak) there are periodically flooded areas bounded from the north by the discontinuous Mangyshlak-Caspian "barrier" and forming a large sub-latitudinal trough oriented across the modern
Caspian Sea and giving rise to the Middle Caspian Mangyshlak syneclise (Guliyev et al., 2016). Late Triassic sedimentation over most of the territory is characterized by extensive development of weathering crusts, alluvial, lacustrine and lacustrine-boggy deposits enriched in carbonaceous material.

Thus, by the end of the Triassic, a vast Middle Caspian trough zone is isolated, which arose on the site of the Central Caspian continental massif that once existed here and the deep Paleozoic strait to the north of it. The scattered remnants of the massif have survived as small hills and low plateaus. This area in the north and northwest is limited by the ridge uplifts of Mangystau and the southern zone of the Karpinsky ridge, and in the south - by the upland of the Karabogaz massif (Guliyev et al., 2018). Its formation is accompanied by the manifestation of volcanism, signs of which are established both in the lower and in the upper parts of the Triassic sections.

In the southwest, the trough area is connected with the deep-water basin of the Greater Caucasus through a number of straits. In the western part of this area, a system of narrow and relatively shallow troughs is formed, which are shelf bays that penetrate far into the continental region and are separated by periodically flooded strips of low flat land.

Early Jurassic (Fig. 1). The boundary of the Late Triassic and Early Jurassic is characterized by a regional hiatus in sedimentation, corresponding to the Early Cimmerian phase of activation of tectonic movements. At this time, there was a slight reduction in the area of sea basins, the distribution of which at the beginning of the Jurassic was limited to the Middle Caspian and the regions of the Plain Dagestan adjacent to it from the west. At the same time, there is a deepening and expansion of the sea basin that occupied the area of the modern Greater Caucasus, where thick flysch strata accumulated. Despite the fact that at this time in the regions adjacent to the Middle Caspian, the conditions of arched uplifts are still preserved, a tendency for their decrease in the northwestern Caspian, Emben region, Mangyshlak and Karabogaz-Tuarkyr region becomes noticeable. This is most likely due to a significant slowdown in the rate of uplifts and the predominance of denudation processes over tectonic uplift in the crestal regions, that is, with the geomorphological leveling of the land and the beginning of downward movements within it. The latter correspond to the early phases of a new marine transgression, covering the Caspian region in the middle - late Early Jurassic. Thus, continental landscapes prevail in the territories of the modern Caspian Sea, North Caspian, Ustyurt and Mangyshlak. Sediment formation here occurs in the conditions of river valleys, lakes and bogs, where terrigenous carbonaceous sections accumulate. 

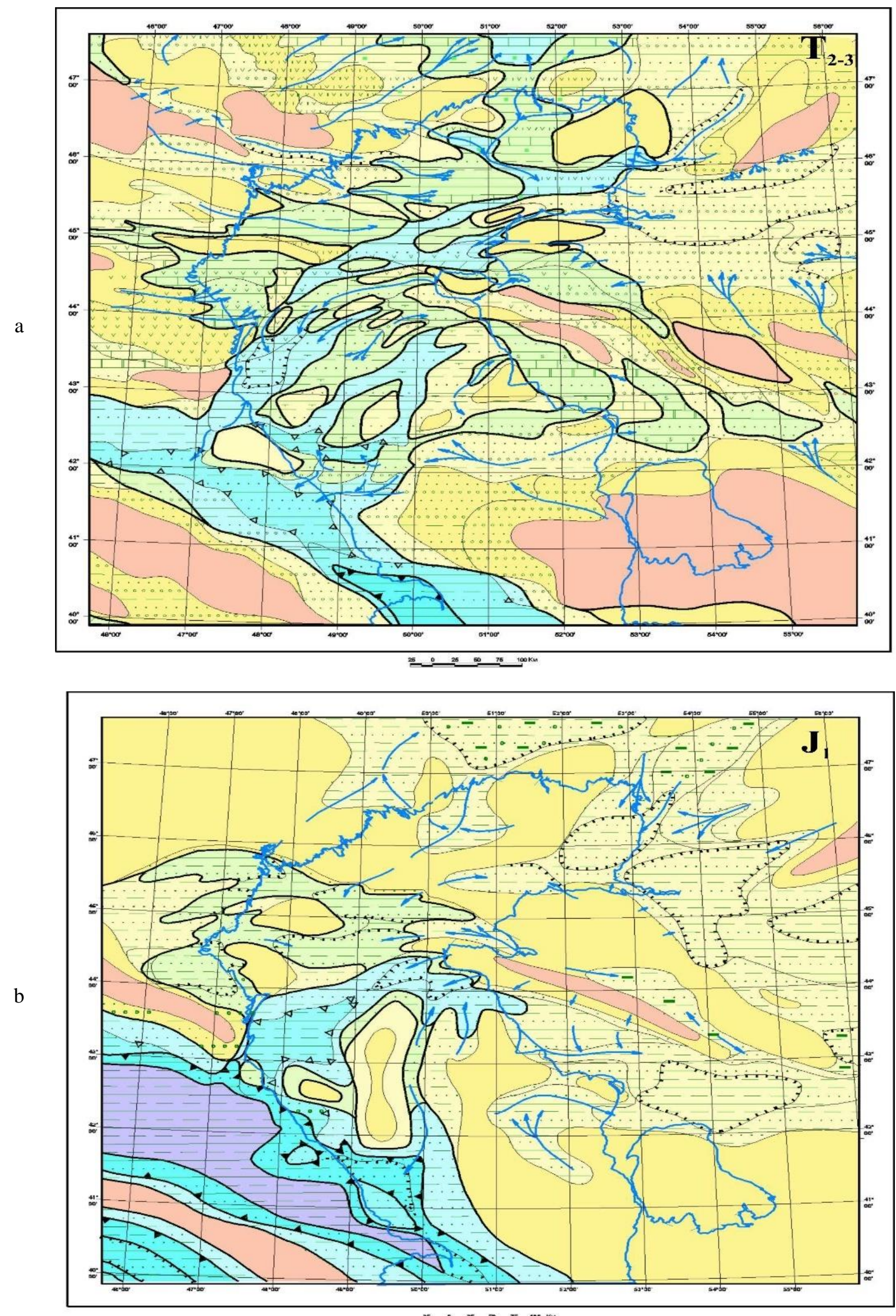

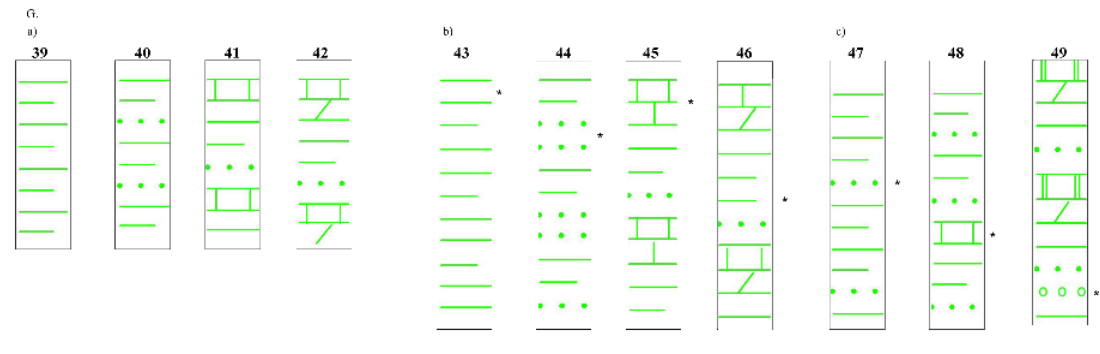

Fig. 1. Lithological-paleogeographic map of the Caspian region. Middle Triassic (a); Early Jurassic (b)

Legend: I - Thickness maps: 1 - equal thickness lines; 2 - areas of no deposits; II - Lithological and paleogeographic maps: A Continental areas: 3 - heights, mountains; 4 - rolling plains, insular land; 5 - plains; B - Transition zones: lowlands, low seaside plains periodically flooded by the sea; shallow periodically drained shelves (estimated paleo-depths up to $20 \mathrm{~m}$ ); $\mathrm{C}-\mathrm{Maritime}$ areas: 7 - inland, shoal shelf; undivided shelf (estimated paleo-depths 0-200 m); 8-outer, deep-sea shelf; overburden basins of inland shelf (estimated paleo-depths 200-1000 m); 9 - continental slope; deep-sea basins on continental and subcontinental crust (estimated paleo-depths up to $2000 \mathrm{~m}$ ); 10 - deep-sea basins on oceanic and suboceanic crust (estimated paleo-depths more than $2000 \mathrm{~m}$ ); $D$ - Outlines notation: 11 - outer shelf lip; 12 - contour of areas of variable continental-marine regime; 13 - inland shelf lip; 14 contour of large paleogeomorphological provinces in the continental area; 15 - outer heights, local hills, basins and terrace ledge; 16 - contour of supposed paleovalleys and sinkholes; 17 - supposed terrestrial and subaqueous estuary complexes of valleys and sinkholes (deltas and alluvial fans); 18 - probable directions of drift of precipitation; 19 - sediments discharge zone; E - Lithological-formation complexes: 20 - dolomites; 21 - limestones; 22 - argillaceous limestones, marls; 23 - clays, argillites; 24 - sandy clays, clayey sands; 25 - silts, siltstones; 26 - sands, sandstones; 27 - gravels, shingles, gravelites, conglomerates; 28 - volcanic formations of different composition; 29 - volcanic-clastic including tuffaceous rocks of different composition; 30 - evaporites; $F$ Other notations: 31 -reefs, bioherms; 32 - calcareous rocks; 33 - charred detritus; 34 - coal; 35 - bituminous rocks; 36 - glauconite; 37 - phosphorite; 38 - contour of lithological-formation provinces; $G$ - examples of rock rotation; a - rock rotation without a visible predominance of one of them; 39 -for two types of rocks; 40 -for three types of rocks; 41 -for four types of rocks; 42 -for five types of rocks; $b$ - rock rotation with predominance of one of them (* - predominant type); 43 -for two types of rocks; 44 -for three types of rocks; 45 -for four types of rocks; 46 - for five types of rocks; c-rock rotation with subordination of one of them (* subordinate type); 47 - for three types of rocks; 48 - for four types of rocks; 49 -for five types of rocks; Perspective structures: 1 Kirovsko-Karalatskaya; 2 - Belinskaya; 3 - Kurmangazy; 4 - Petrovskaya; 5 - Zyudevskaya; 6 - Caspian; 7 -Morskaya; 8 Osetrovaya; 9 - Central-Rakushecnaya; 10 - East-Rakushecnaya; 11 - Shirotnaya; 12 - Tyub-Karaganskaya; 13 - Yuzhnaya; 14 Sarmatskaya; 15 -Druzhba; 16 - Khvalinskaya; 17 - 170 km; 18 -Segendik-sea; 19 -Centralnaya; 20 - Yalama-Samur

Areas of the shallow shelf, together with the periodically flooded lowlands of the Eastern Ciscaucasia (Vostochno-Manychskaya and Kizlyarskaya), had rather complex contours inscribed in the outlines of the swell-like elevations of the Karpinsky and Mangyshlak ridge. The generalized contour of the coastline passed in the east approximately in the middle of the present-day Caspian, and in the area of the Mangyshlak trough it turned westward, following along the southern boundary of the Kulalinsky and Poldnevsky swells. In shallow sea depressions, mainly terrigenous sediments accumulated.

In the western part of the Middle Caspian trough area, at the site of a series of Triassic troughs, a relatively deep-water Segendyk Bay is formed, belonging to the deep-water sea or suboceanic basin of the Greater Caucasus - South Caspian. The previously separated northern limits of the Middle Caspian diving region unite and form an extended system of swell-like hills, a kind of barrier or threshold that separates the North and Middle Caspian sedimentation regions.

Middle Jurassic (Fig. 2).At this time, the development of the Middle Mesozoic marine transgression continues, the early phases of which, associated with the expansion of the Tethys Ocean that began in the Triassic or Late Permian, manifested themselves here in the Early Jurassic. Apparently, this process is responsible for an insignificant differentiated activation of areas of arched uplifts in the southern and eastern regions of the platform. It led to the mobilization of surface runoff, the formation of pronounced river valleys and the formation of terrestrial and submarine delta complexes, especially characteristic of the northeastern (Ural) margins of the region.

The transgression is accompanied by a sharp reduction in the zones of continental sedimentation. It was preserved mainly in areas adjacent to the southern tip of the Paleoural Orogen, where sedimentation took place in the conditions of river valleys and low swampy plains, and along the periphery of the most contrasting uplifts (Karabogaz, the Caspian zone).

In this epoch, the channels connecting the basins of the North and Middle Caspian are renewed, and the latter turns out to be completely open to the south, to the deep-water basins of the Caucasus South Caspian. Some obstacle on the paths of bottom material transfer from the Middle Caspian to the south could be represented by the zone of shelf ele- 
vations in the strip of the modern DagestanAzerbaijan coast. Thus, the areas of stable shelf regimes in the Middle Jurassic cover practically the entire modern Caspian and Caspian regions, and the region of the Eastern Ciscaucasia adjacent to them from the west. At the same time, the deepest shelf zones (outer or over-deepened shelf) are concentrated within the contour of the modern Caspian. The western part of the sea basin is replete with shoals and low, periodically flooded swampy islands, forming a picture of a "skerry sea".

In the areas of southern Emba, Ustyurt and Mangyshlak, the regimes of alternation of a shallow sea and a low-lying accumulative coastal plain are established (Керимов и др., 2015). Lowlands and shallow shelf basins are separated by low, sparse ridge uplands with flat relief.

More contrasting hilly or low-mountainous land areas are characteristic only for the southern zone of this region. In the deep-water area of the Greater Caucasus - South Caspian, the differentiation of the previously unified basin into a number of zones separated by elevated ridges, and some shallowing of these zones, are apparently taking place.

The latter could be partly due to the intensification of sedimentation due to the influx of large volumes of clastic material both from the north, from the side of the platform, and from newly formed ridges (cordilleras) that arose in the basin system.

The Late Jurassic (Fig. 2) is generally defined as an epoch of ongoing marine transgression with a relatively calm tectonic regime, with a predominance of subsidence in the platform area and expansion of uplift zones, with a simultaneous reduction of deep-water basins in the Caucasus zone.

It is assumed that at this time there were wide straits that connected the Caspian, Barents and Baltic paleobasins (Kerimov et al., 2018).The continuation of the transgression contributed to the emergence of a stable shelf regime in the east of the region, where previously variable continentalmaritime environments existed.

On the northern periphery of the CaucasianSouth Caspian system of deep-water basins, the formation of a system of barrier uplifts and scarps, which separates the shelf area from deep-water basins, is again activated. A similar system of barrier uplifts, partially protruding from the sea level, again (after the Triassic and Early Jurassic) is also formed between the basins of the Middle and North Caspian (Лебедев и др., 1987).

Thus, in the Late Jurassic epoch, apparently, for the first time, a three-link system of basins (megabasins) of the Caspian region was clearly formed, with its North, Middle and South Caspian sectors, which are separated by systems of barrier uplifts.
Early Cretaceous (Fig. 3). The Cretaceous epoch is generally characterized by the tectonic subsidence of the platform area, against which the development of marine transgression continues (Керимов и др., 2014). In the Early Cretaceous, the paleogeographic appearance of the region, which existed in the Late Jurassic, is preserved in the main features. At this time, shelf channels continue to expand, connecting the Caspian paleobasin with the Western (Barents Sea) Arctic through the Pechora syneclise. This connection begins to break in the Aptian age and completely ceases in the Albian. However, at the same time, shelf straits which connect the Caspian paleobasin with Western Siberia and the Kara Sea appear.

In the conditions of a vast, relatively shallowwater basin, there is a further reduction in the size and decrease of the island heights of the platform area, accompanied by their periodic flooding. This process was most contrastingly manifested in the region of the Karabogaz arch, which for a long time existed in the form of a large elevated island. In the main, a high degree of dissection of the shallowwater shelf and accordingly the differentiation of lithological complexes of sediments are preserved (Kerimov et al., 2018). However, terrigenous, sandyargillaceous deposits are significantly predominant. Sections containing carbonate units are formed mainly in shelf depressions remote from erosion areas or in semi-isolated shallow-water depressions bounded by low-lying islands. Zones of predominant development of sections containing carbonates (limestones, marls, less often dolomites) tend to the southern margin of the paleobasin.

In general, the division of the paleobasin into three sedimentary systems by zones of barrier uplifts, which are noticeably reduced, remains. Some of them go under sea level and are transformed into shelf heights.

Late Cretaceous (Fig. 3). The conditions of tectonic subsidence and transgression in this epoch reach apparently their maximum development. Almost the entire area of the platform within the region is occupied by the shelf sea with rare islands, which are concentrated in the zone of modern Mangyshlak and along the southern margin of the platform. The largest tracts of island land are located here. Basins of this epoch are mainly characterized by carbonate sedimentation. However, in the northern part of the paleobasin, limited by a system of seamounts along the Mangyshlak - Karpinsky Ridge line, a noticeable portion of terrigenous material appears in the sediment section. In the Transcaucasian part of the region, especially in deep-water basins, terrigenous sedimentation seems to prevail over carbonate sedimentation. Limestone strata forming carbonate platforms accumulate here in zones of narrow shelf plateaus separating deep-sea trenches. 

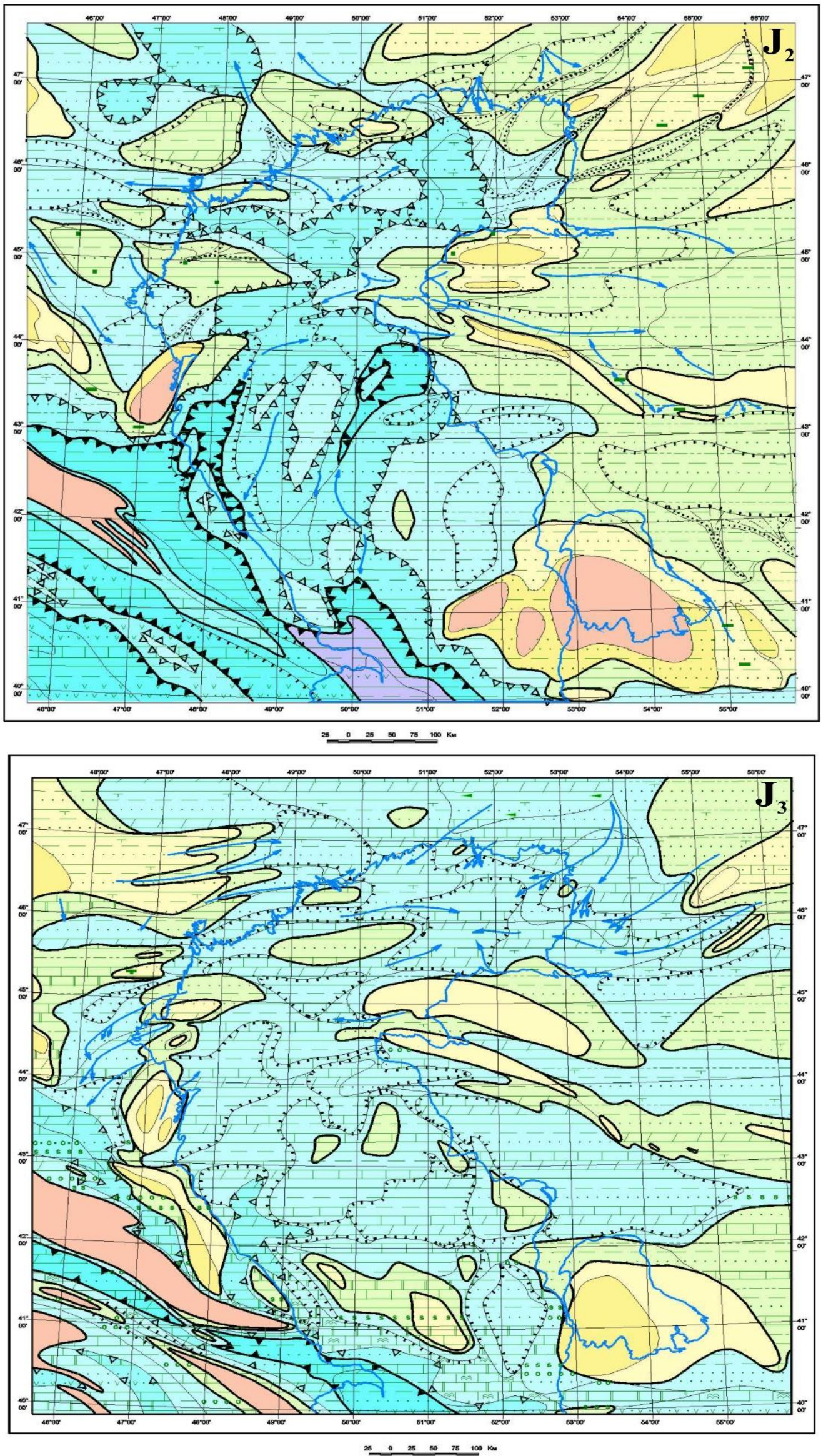

Fig. 2. Lithological-paleogeographic map of the Caspian sub-region. Middle (a)-Late (b) Jurassic Legend: see fig. 1 

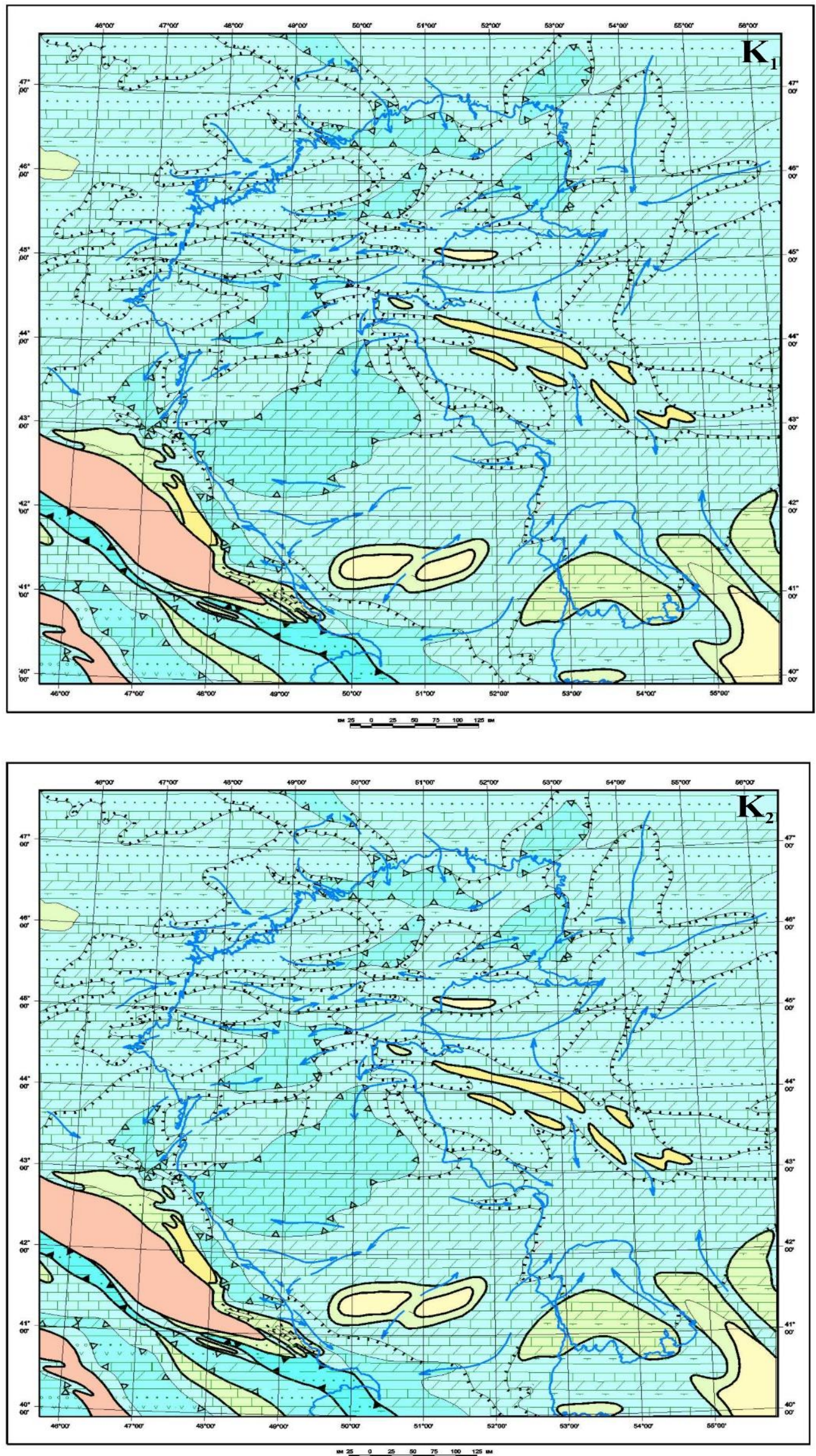

Fig. 3. Lithological-paleogeographic map of the Caspian subregion. Early (a) - Late (b) Cretaceous Legend: see fig.1. 
The continuing subsidence of the shelf leads to the emergence within its limits, in place of previously existing depressions, over-deepened closed shelf basins. The sedimentation conditions in them are comparable to those of real deep-water basins. The distribution of these basins indicates that the zone of maximum subsidence of the Late Cretaceous paleobasin in the regions of the Middle and North Caspian approximately corresponded to the modern axis of the Caspian Sea.

The shelf sea, which existed in the south of the present-day Middle Caspian, is separated from the Transcaucasian - South Caspian deep-water basin by a barrier that still retained its expressiveness, but already significantly reduced and smoothed. The western part of the barrier is crossed by the relatively deep-water East Dagestan trough, which extends along the northeastern slope of the Caucasus mountain structure to the deep-water basin.

In the Paleocene-Eocene, the platform areas of the Middle and North Caspian generally retained the sedimentation regime inherited from the Late Cretaceous period. The shelf region occupied most of the Caspian Basin and the Eastern Ciscaucasia in the Paleocene, and their accumulated clays, marls, siltstones, sands and clayey limestones. The deepest part of the shelf was located between the Volga and Ural rivers, as well as in the eastern part of the Karpinsky ridge, where carbonate-clayey and siliceous-clayey silts were deposited. In the Eocene, the position of the shelf did not change. The expansion of the transgression in the Eocene (after a short phase of regression in the Late Paleocene) led to the restoration of the connection between the Caspian and West Arctic basins through the so-called Turgai Strait. The nature of sedimentation has changed little compared to the Paleocene - under the conditions of a relatively shallow shelf, the deposition of clays, marls, siltstones, sands, and sometimes limestones continued.

In the Oligocene-Early Miocene (Maykopian age) (Fig. 4), the conditions of sedimentation in the Middle and North Caspian Sea changed significantly. At this time, active orogenic processes in the zone of the Greater Caucasus and Mangyshlak and the formation of arched uplifts associated with them in the vast territories of the Scythian and Turanian platforms began. At this time, in the shallow shelf basins of the Middle and North Caspian, there was an accumulation of sandy-clayey sediments brought here from the East European platform. The beginning of the Oligocene was associated with the formation of Paratethys, a single, large basin of the Black Sea - Caspian region partially isolated from the ocean. As noted by many researchers (Холодов, Туровский, 1985), isolation influenced the condi- tions of sedimentation through hydrogen sulfide contamination of the environment and a significant depletion of the fauna corresponding to the deposits of the Maykop Group. These conditions persisted in the Miocene, while the isolation of the Black Sea and Caspian segments of the region increased. Specific conditions for hydrogen sulfide contamination existed until the middle of the Miocene.

A single depression formed in Maykop in the space from the Karpinsky ridge to the southern slopes of the Mangystau ridge. The thickness of the deposits in it reaches $2000 \mathrm{~m}$ (Rachinsky, Kerimov, 2015). The Maykop Sea was to a large extent a deep-water basin here. Its continental slope is clearly recorded at the foot of the Caucasus in the south and on the southern slopes of the Karpinsky Ridge in the north.

On the largest uplifts in the eastern part of the Karpinsky ridge, the deposits of the Maykop Formation are eroded. In other parts of the ridge and in the adjacent territories of the East European platform, their thickness is $200-300 \mathrm{~m}$ and decreases to the north to $100 \mathrm{~m}$ or less.

Intensive uplifts in the Upper Oligocene - Lower Miocene led to the expansion of land and erosion zones on the eastern coast of the Caspian. The Late Miocene transgression destroyed the deposits of the Maykop Formation over significant areas. The erosion zone was the uplift of the Central Ustyurt and Buzachinsky arches. In the shallow-water basins of the Caspian Basin in the Oligocene, accumulation of predominantly clayey deposits with interlayers of siltstones and sandstones took place (Атлас литолого-палеогеографических карт СССР, 1967). Маrine sedimentation was sometimes replaced by continental sediments, and during these periods there was an accumulation of sandy-clayey coal-bearing deposits. In the early Miocene, the Caspian lowland was covered by a general regional uplift.

Continental conditions established for a long time led to the erosion of older sediments, primarily Oligocene, which in places survived only in deep interdome zones in the central and southeastern part of the lowland, where deposits of the Lower Miocene are also possible (Левин, Сенин, 2003).

The regional uplift of the Northern Caspian and the adjacent territories of the Scythian and Turan plates led to an almost complete erosion of the Maykop complex, which has survived only in local depressions, where its thickness does not exceed 300$500 \mathrm{~m}$.

In the central and southern zones of the Middle Caspian, a group of uplands corresponding to the buried Samur-Peschanomyssk zone of uplifts acquires a distinct expression. In the straits that separate these uplands, deep erosion trenches are formed 
in places, inheriting ancient faults in the Mesozoic sediments (Senin, 2012). One of these underwater trenches, deeply cut into the Mesozoic substrate (Middle Caspian trench), separates the group of low islands Yalama-Samur-Central from the Peschanomyss Upland. Its mouth part is possibly associated with the formation of an extensive flat underwater fan, which is reconstructed according to the peculiarities of the distribution of the thickness of the Maykop deposits.

At the boundary of the Early and Middle Miocene, significant areas of the Scythian and Turanian plates, with the exception of the most bowed parts of the depressions, were involved in a short-term uplift.
After that, a new cycle of transgression began. The maximum subsidence in the Tersko-Caspian foredeep occurred in the Middle Miocene, when more than $1.500 \mathrm{~m}$ of sediments accumulated here.

The amplitude of the subsidence of the western part of the Turan plate at that time was much smaller. In the Late Miocene, the South Mangyshlak Trough was the main subsidence area here.

The development of the southern part of the Caspian Basin in the Middle-Late Miocene was characterized by uplift and erosion of underlying sediments. In the water area of the Northern Caspian, the Middle-Upper Miocene complex is eroded, its residual thickness does not exceed $100 \mathrm{~m}$.

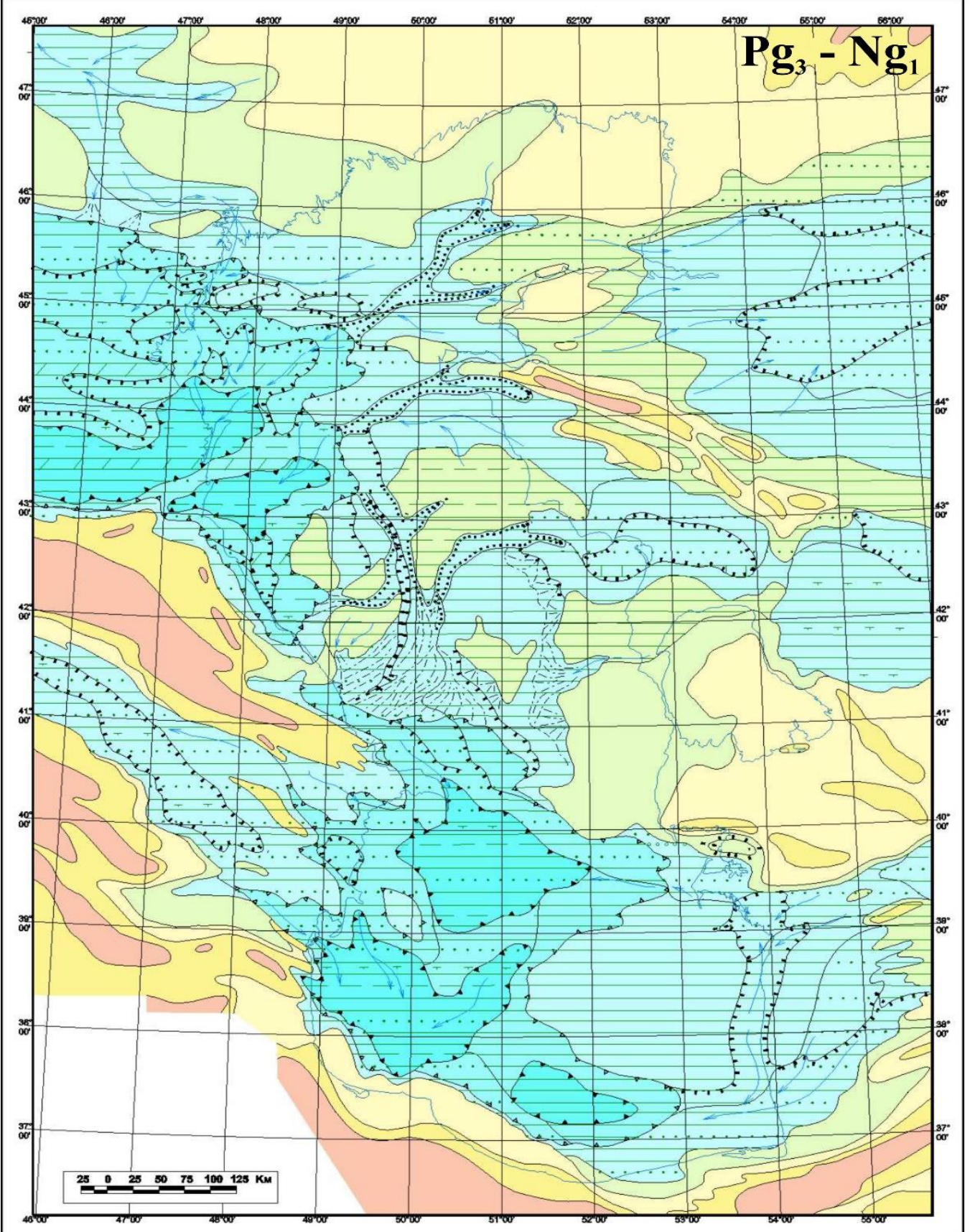




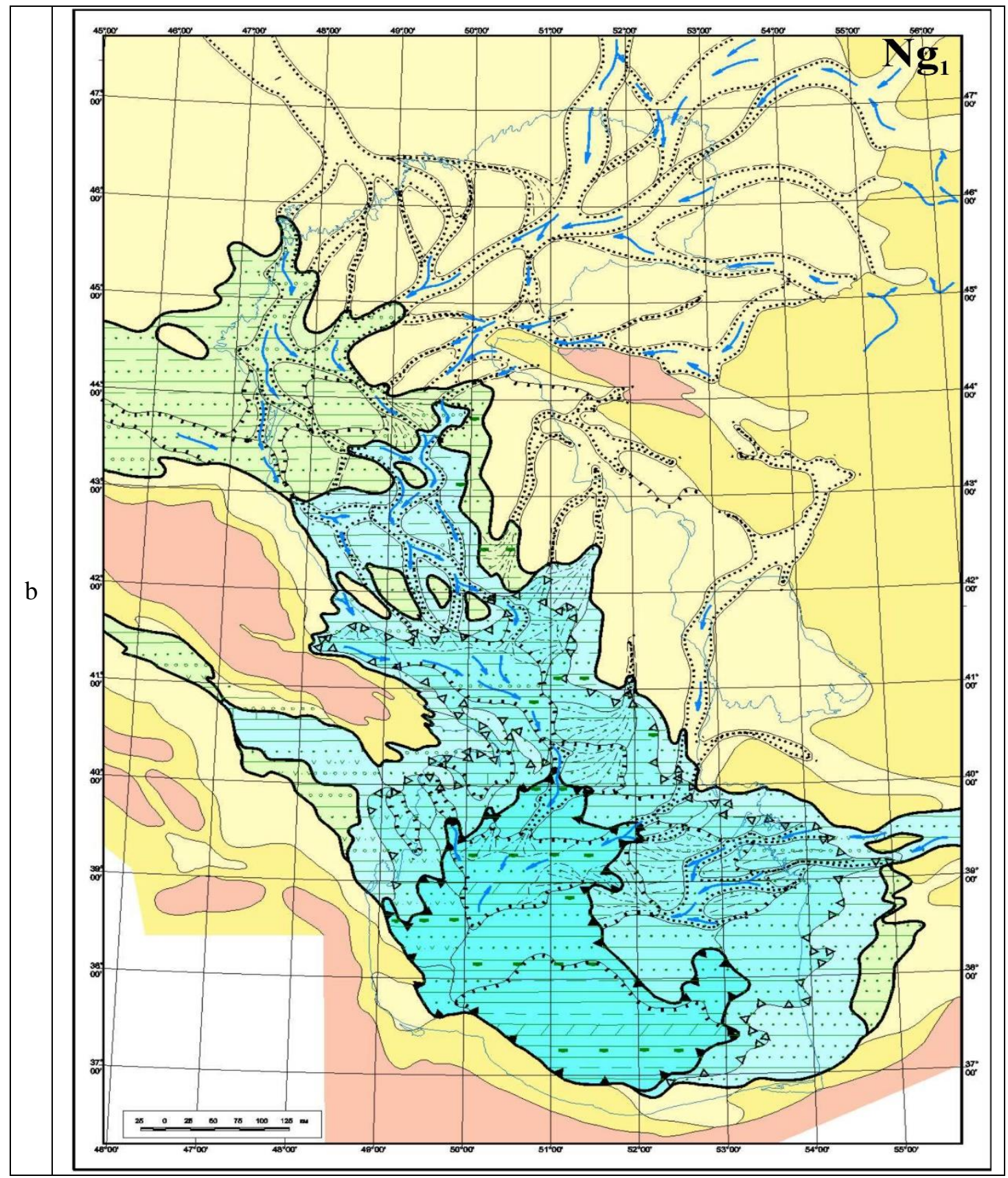

Fig. 4. Lithological-paleogeographic map of the Caspian subregion. Oligocene-Miocene (Maykopian age) (a) - Pliocene (Balakhanian age) (b) Legend: see fig.1.

By the Middle Pliocene (Fig. 4), stable conditions of the shallow shelf were preserved only in the areas adjacent to the eastern part of the Caucasian Orogen. In the more western regions of the Eastern Ciscaucasia, sedimentation conditions of alternation of a shallow sea and a low accumulative plain were established. To the north and east of them, continental conditions were established almost until the end of the Neogene. At this time the platform areas of the Middle and North Caspian were raised (or there was a sharp drop in sea level under conditions of significant climate aridization). On the territory of the East European Platform and in the Urals, the formation of a deeply incised river network began. The most pronounced paleovalleys of this time are Paleo-Volga and Paleo-Ural.

Areas of overdeep shelf formed at this time in the southern zone of the Middle Caspian and along the periphery of the South Caspian depression, the western part of which is occupied by a relatively deep-water basin, roughly corresponding to the modern deep-water basin of the South Caspian (Senin, 2012).

In the Priabsheron region, a system of deepwater lagoons is formed, separated from the South Caspian depression by underwater structural-accumulative formations. The latter are slowly growing 
at this time into consedimentary folds, above which sandy, sandy-clayey, or sandy-pebble shoals are formed in the form of underwater spits, bars, and swells bordering the eastern plunge of the Caucasian Orogen. The clastic material that forms these bodies comes as a result of drift from the orogenic area and multi-stage transfer from more northern and western regions, both as a result of alongshore transit, and through a system of conjugated land and submarine canals that form a series of intermediate areas of unloading on their way - underwater and land deltas and fan. The final accumulative body of this system in the form of an underwater alluvial cone is most likely formed in the middle part of the AbsheronPribalkhan sille.

The modern morphology of the Caspian basin was finally determined in the Quaternary period. The most significant structural change at this time was the formation of a submeridional depression along the western coast of the sea. It is explained by the active submersion of this zone, the rate of which in the last $70-75$ years can be $4-6 \mathrm{~mm}$ per year or more. The deep-water basins of the Middle and South Caspian, characterized by some features of sedimentation and folding, are formed near the intersections of this depression with the systems of alpine troughs of the Caucasian direction (Tersko-Caspian trough and Kura intermontane trough). At present the same process of forming a nodal depression is possible in the southwestern part of the Volga delta and in the Ukatnenskaya depression, north of the Kurmangazy uplift. However, this process can be completely compensated by sediments from the Volga estuary and masked by its Quaternary delta.

\section{Conclusion}

Thus, the studies carried out allowed us to study the lithological and paleogeographic conditions of the formation and distribution of sedimentary basins of the Caspian region. This is necessary for further numerical basin modeling.

Non-palinspastic lithological-paleogeographic reconstructions, performed using classical methods of thickness and facies analysis, showed that in the Middle-Late Triassic and Early Jurassic continental conditions prevailed in most of the Caspian region with the accumulation of terrigenous, less often car- bonate, and in some places volcanogenic sedimentary strata. In the Middle Jurassic, large areas of stable subsidence and inundation appeared, and in the Late Jurassic and Early Cretaceous, predominantly marine conditions were established in the region with a predominance of carbonate sedimentation in some zones. In the Late Cretaceous, the entire region was a clay-carbonate shelf, in places over-deepened. At the end of the Paleogene - Early Miocene, in the southern part of the region, the processes of arch formation and orogenesis intensified, which were accompanied by the draining of the zones of orogenesis and some areas of the Northern and Eastern Caspian Sea, and the formation of over-deepened shelf troughs ahead of the front of the zone of active orogenesis with the predominance of terrigenous sedimentation in them. Substantial drainage of the territory of the Middle and North Caspian took place in the Pliocene, when in the relict, relatively deep sea depressions of the South and the Middle Caspian region south of $42^{\circ} \mathrm{N}$ lat. formed powerful delta complexes of Pliocene rivers flowing from the East European platform and, in part, from the Turan plate.

The results of the reconstructions made it possible to restore the conditions and environments of sedimentation characteristic of the Caspian region in a long historical and geological retrospective and to obtain the necessary information for the subsequent numerical modeling of sedimentary basins and the evolution of their hydrocarbon systems.

\section{Discussion of the results and conclusions}

Based on the obtained data, a graph of the dependence of the incident angle and azimuth of the considered seismic waves at 34 time intervals was constructed. As can be seen in the graph at the first 4 points corresponding to the longitudinal wave, the azimuth fluctuates in the range of $140-155^{\circ}$, and the incident angle $-15-37^{\circ}$. For linearly polarized oscillations, the recording form is preserved and the oscillations are in phase, regardless of the orientation of the components in space. The nature and polarization of the longitudinal wave are independent of the source and the forces acting in it. Therefore, at each individual observation point, the nature of the polarization of wave $\mathrm{P}$ caused by the earthquake will be the same and cannot provide information about the source. 


\section{REFERENCES}

Aliev M.M. Paleogeographic setting in the Cretaceous period in the southeast of the Greater Caucasus. In the book: Stratigraphy and paleogeography of oil and gas bearing areas of young platforms. Nauka. Moscow, 1982, pp. 6-23 (in Russian).

Atlas of lithological and paleogeographic maps of the USSR. Vol. III-IV. MG USSR, Academy of Sciences of the USSR, Main Directorate of Geodesy and Cartography of the USSR Ministry of Geology. Moscow, 1967 (in Russian).

Belousov V.V. Fundamentals of geotectonics. Nedra. Moscow, 1989, 382 p. (in Russian).

Glumov I.F., Gulev V.L., Senin B.V., Karnaukhov S.M. Regional geology and oil and gas prospects of the Black Sea deepwater depression and adjacent shelf zones. In 2 parts. Nedra publishing house. Moscow, 2014, P.I, 279 p.; P.II, 181 p. (in Russian).

Guliyev I.S., Kerimov V.Yu., Mustaev R.N., Bondarev A.V. The Estimation of the Generation Potential of the Low Permeable Shale Strata of the Maikop Caucasian Series, SOCAR Proceedings, No. 1, 2018, pp. 4-20.

Guliev I.S., Kerimov V.Yu., Mustaev R.N. Fundamental challenges of the location of oil and gas in the South Caspian basin. Doklady Earth Sciences, Vol. 471, No. 1, 2016, pp.1109-1112.

Kerimov V.Yu., Guliev I.S., Guseinov D.A., Lavrenova E.A., Mustaev R.N., Osipov A.V., Serikova U.S. Forecasting oil and gas content in regions with complex geological structure. Publishing house Nedra. Moscow, 2015, 404 p. (in Russian)

Kerimov V., Rachinsky M., Mustaev R., Serikova U. Geothermal conditions of hydrocarbon formation in the South Caspian basin. Iranian Journal of Earth Sciences, Vol. 10, No.1, 2018, pp. 78-89.

Kerimov V.Y., Mustaev R.N., Osipov A.V. Peculiarities of hydrocarbon generation at great depths in the crust. Doklady Earth sciences, Vol. 483, No. 1, 2018, pp. 1413-1417.

Kerimov V.Y., Rachinsky M.Z., Mustaev R.N., Osipov A.V. Groundwater dynamics forecasting criteria of oil and gas occurrences in alpine mobile belt basins. Doklady Earth Sciences, Vol. 476, No. 1, 2017, pp. 1066-1068.

Kerimov V.Yu., Serikova U.S., Mustayev R.N., Guliyev I.S Deep oil-and-gas content of South Caspian Basin. Neftyanoe khozyaystvo - Oil Industry, No. 5, 2014, pp. 5054 (in Russian).

Kholodov V.N., Turovsky D.S. On the problem of sedimentation in the Caspian Sea. Litologiya i poleznye iskopaemye, No. 1, 1985, pp. 17-34

Lebedev L.I., Aleksina I.A., Kulakova L.S. Caspian Sea: geology and oil and gas potential. Nauka. Moscow, 1987, 296 p. (in Russian).

Leonov Yu.G. Tectonic criteria for the interpretation of seismically reflecting horizons in the lower crust of continents. Geotektonika, No. 5, 1993, pp. 4-15 (in Russian).

Levin L.E., Senin B.V. Deep structure and dynamics of sedimentary basins in the Caspian region. Doklady Akademii nauk, Vol. 338, No. 2, 2003, pp. 216-219 (in Russian).

Rachinsky M.Z., Kerimov V.Yu. Fluid dynamics of oil and gas reservoirs. Scientific Editor Gorfunkel M.V. Wiley-Scrivener Publishing. USA, 2015, 640 p.

Senin B.V. Model of regional tectonics and hydrocarbon potential offshore Russia and foreign sectors of the Black Caspian region. 5th EAGE St.Petersburg International Conference and Exhibition on Geosciences - Making the Most of the Earth's Resources, Conference proceedings, 2012, https://doi.org/10.3997/2214-4609.20143603

\section{ЛИТЕРАТУРА}

Алиев М.М. Палеогеографическая обстановка в меловой период на юго-востоке Большого Кавказа. В кн.: Стратиграфия и палеогеография нефтегазоносных областей молодых платформ. Наука. Москва, 1982, с. 6-23.

Атлас литолого-палеогеографических карт CCCP. T. III-IV. МГ СССР, АН СССР, Главное управление геодезии и картографии Министерства геологии СССР. Москва, 1967.

Белоусов В.В. Основы геотектоники. Недра. Москва, 1989, $382 \mathrm{c}$.

Глумов И.Ф., Гулев В.Л., Сенин Б.В., Карнаухов С.М. Региональная геология и перспективы нефтегазоносности Черноморской глубоководной впадины и прилегающих шельфовых зон. В 2-х частях. Издательский дом Недра. Москва, 2014, Ч.I, 279 с.; Ч.ІІ, 181 с.

Guliev I.S., Kerimov V.Yu., Mustaev R.N. Fundamental challenges of the location of oil and gas in the South Caspian basin. Doklady Earth Sciences, Vol. 471, No. 1, 2016, pp.1109-1112.

Керимов В.Ю., Гулиев И.С., Гусейнов Д.А., Лавренова Е.А., Мустаев Р.Н., Осипов А.В., Серикова У.С. Прогнозирование нефтегазоносности в регионах сосложным геологическим строением. Издательский дом Недра. Москва, 2015, $404 \mathrm{c}$

Kerimov V.Y., Mustaev R.N., Osipov A.V. Peculiarities of hydrocarbon generation at great depths in the crust. Doklady Earth sciences, Vol. 483, No. 1, 2018, pp. 1413-1417

Керимов В.Ю., Рачинский М.3., Мустаев Р.Н., Осипов А.В. Геофлюидодинамические критерии прогнозирования нефтегазоносности в регионах Альпийской складчатости. Доклады Академии наук, Т. 476. №. 2, 2017, с. 209-212.

Керимов В.Ю., Серикова У.С., Мустаев Р.Н., Гулиев И.С. Нефтегазоносность глубокозалегающих отложений Южно-Каспийской впадины. Нефтяное хозяйство, №. 5, 2014 , c. $50-54$

Холодов В.Н., Туровский Д.С. К проблеме осадконакопления в Каспийском море. Литология и полезные ископаемые, No.1, 1985, с. 17-34.

Лебедев Л.И., Алексина И.А., Кулакова Л.С. Каспийское море: геология и нефтегазоносность, Наука. Москва, $1987,296 \mathrm{c}$.

Леонов Ю.Г. Тектонические критерии интерпретации сейсмически отражающих горизонтов в нижней коре континентов. Геотектоника, No. 5, 1993, с. 4-15.

Левин Л.Э., Сенин Б.В. Глубинное строение и динамика осадочных бассейнов в Каспийском регионе. ДАН, Т. 338, No. 2, 2003, c. 216-219.

Guliyev I.S., Kerimov V.Y., Mustaev R.N., Bondarev A.V. The Estimation of the Generation Potential of the Low Permeable Shale Strata of the Maikop Caucasian Series. SOCAR Proceedings, No. 1, 2018, pp. 4-20.

Kerimov V., Rachinsky M., Mustaev R., Serikova U. Geothermal conditions of hydrocarbon formation in the South Caspian basin. Iranian Journal of Earth Sciences, 2018, Vol. 10, No. 1, pp. 78-89.

Rachinsky M.Z., Kerimov V.Yu. Fluid dynamics of oil and gas reservoirs. Scientific Editor Gorfunkel M.V. Wiley-Scrivener Publishing. USA, 2015, $640 \mathrm{p}$.

Senin B.V. Model of regional tectonics and hydrocarbon potential offshore Russia and foreign sectors of the Black sea Caspian region. 5th EAGE St. Petersburg International Conference and Exhibition on Geosciences - Making the Most of the Earth's Resources, Conference proceedings, 2012, https://doi.org/10.3997/2214-4609.20143603 


\title{
ЛИТОЛОГИЧЕСКИЕ И ПАЛЕОГЕОГРАФИЧЕСКИЕ УСЛОВИЯ ФОРМИРОВАНИЯ И РАЗМЕЩЕНИЯ ОСАДОЧНЫХ БАССЕЙНОВ КАСПИЙСКОГО РЕГИОНА
}

\author{
Сенин Б.В. ${ }^{1}$, Керимов В.Ю. ${ }^{2}$, Мустаев Р.Н. ${ }^{2}$, Алиева С.А. ${ }^{3}$ \\ ${ }^{1}$ АО «Южморгеология» \\ 353461, Краснодарский край, г. Геленджик, ул. Крымская, д. 20 \\ ${ }^{2}$ Российский государственный геологоразведочный университет имени Серго Орджоникидзе \\ 117997, Москва ул. Миклухо-Маклая д.23: r.mustaev@mail.ru \\ ${ }^{3}$ Азербайджанский университет нефти и промышленности \\ AZ1010, Баку, Азербайджан, просп. Азадльг, 16/21
}

Резюме. В статье рассматриваются литологические и палеогеографические условия формирования и размещения осадочных бассейнов Каспийского региона, главной особенностью морфологии и структуры которой является наличие здесь сверхглубоких впадин. Исследование охватывает геохронологический интервал от среднего триаса по балаханское время плиоцена. Непалинспастические литолого-палеогеографические реконструкции, выполненные с использованием классических методов анализа мощностей и фаций, показали, что в среднем-позднем триасе и ранней юре на большей части Каспийского региона преобладали континентальные условия с накоплением в отдельных бассейнах терригенных, реже карбонатных, а местами и вулканогенно-осадочных толщ. В средней юре появились крупные районы устойчивого погружения и затопления, а в поздней юре и раннем мелу в регионе установились преимущественно морские условия с преобладанием в некоторых зонах карбонатного осадконакопления. В позднем мелу весь регион представлял собой глинисто-карбонатный шельф, местами переуглублённый. В конце палеогена - раннем миоцене в южной части региона активизировались процессы сводообразования и орогенеза, которые сопровождались осушением зон орогенеза и некоторых районов Северного и Восточного Каспия и образованием переуглублённых шельфовых прогибов перед фронтом зоны активного орогенеза с преобладанием в них терригенного осадконакопления. Существенное осушение территории Среднего и Северного Каспия произошло в плиоцене, когда в реликтовых, относительно глубоководных морских впадинах Южного и района Среднего Каспия к югу от $42^{\circ}$ С.Ш. формировались мощные дельтовые комплексы плиоценовых рек, текущих с Восточно-Европейской платформы и, отчасти, с Туранской плиты.

Результаты реконструкций позволили восстановить свойственные Каспийскому региону условия и обстановки осадконакопления в длительной историко-геологической ретроспективе и получить необходимую информацию для последующего численного моделирования осадочных бассейнов и эволюции их углеводородных систем.

Ключевые слова: Каспийский регион, реконструкция, литологические и палеогеографические условия, осадочные бассейны

\section{XəZכR REGIONUNDA ÇÖKÜNTÜ HÖVZəLəRININ FORMALIŞMASININ Və YERLəŞMəSINININ LİTOLOJI Və PALEOCOĞRAFİ ŞəRAITII}

\author{
Senin B.V. ${ }^{1}$, Kərimov V.Y. ${ }^{2}$, Mustayev R.N. ${ }^{2}$, Oliyeva S.A. ${ }^{3}$ \\ l"Yujmorgeologiya"Sahmdar Camiyyati \\ 353461, Krasnodar bölgasi, Gelencik şah., Krymskaya küç.,20 \\ ${ }^{2}$ Serqo Orconikidze ad. Dövlat Geoloji Kaşfiyyat Universiteti, Rusiya, Moskva \\ 117997, Moskva şəh., Mikluho-Maklay küç., 23: r.mustaev@mail.ru \\ ${ }^{3}$ Azarbaycan Dövlat Neft va Sanaye Universiteti \\ AZ1010, Bakı şəh., Azadlıq prosp., 16/21
}

Xülasə. Məqalədə Xəzər regionunun çöküntü hovzələrinin formalaşmasının və yerləşməsinin litoloji və paleocoğrafi şəraiti nəzərdən keçirilir. Onun morfologiyasının və strukturunun əsas xüsusiyyəti burada ifratdərin çökəklərin olmasıdır.Tədqiqat orta triasdan pliosenin Balaxanı dövrünə qədər geoxronoloji intervalı əhətə edir.

Qalınlıqların və fasiyaların təhlilinin klassik metodlarından istifadə etməklə yerinə yetirilmiş qeyri-palinspaktik litoloji-paleocoğrafi rekonstruksiyalar göstərmişdir ki, Orta-Gec triasda və erkən yurada Xəzər regionunun böyük hissəsində ayrı-ayrı hövzələrdə terrigen, nadir hallarda karbonat, bəzi yerlərdə isə vulkanogen-çökmə qatların toplanması ilə kontinental şərait üstün olmuşdur. Orta yurada dayanıqlı batma və subasmanın iri rayonları əmələ gəlmiş, gec yurada və erkən təbaşirdə isə bəzi zonalarda karbonat çöküntütoplanmanın üstünlüyü ilə regionda əsasən dəniz şəraiti mövcud olmuşdur. Gec təbaşirdə bütün region, bəzi yerləri yenidən dərinləşmiş, gilli-karbonatlı şelflə təmsil olunmuşdur. Paleogenin sonunda - erkən miosendə regionun cənub hissəsində tagəmələgəlmə və orogenez prosesləri aktivləşmişdir. Bunlar orogenez zonalarının və Şimali və Şərqi Xəzərin bəzi rayonlarının quruması və aktiv orogenez zonasının önündə yenidən dərinləşmiş şelf çökəkliklərinin əmələ gəlməsi ilə, onlarda terrigen çöküntütoplanmanın üstünlüyü ilə, müşayiət olunmuşdur. Orta və Şimal Xəzər ərazisinin mühüm dərəcədə quruması Pliosendə baş vermişdir. Həmin vaxt Cənubi və Orta Xəzər rayonunun $42^{\circ}$ şm. enliyindən cənubda reliktlərdə, nisbətən dərinsulu dəniz çökəkliklərində Şərqi Avropa platformasından və qismən Turan plitəsindən axan Pliosen çaylarının qalın delta kompleksləri formalaşmışdır.

Rekonstruksiyalarının nəticələri uzunmüddətli tarixi-geoloji retrospektivdə Xəzər regionuna xas olan çöküntütoplanma vəziyyəti və şəraitinin bərpasına və çöküntü hövzələrinin gələcək rəqəmli modelləşdirilməsi və onların karbohidrogen sistemlərinin təkamülü üçün lazımi infopmasiyanın alınmasına imkan vermişdir.

Açar sözlər: Xəzər regionu, rekonstruksiya, litoloji və formasion aspektlər, paleocoğrafi kondisiyalar, çöküntü hövzəsi 